\title{
Evaluation of Residual Monomer Release After Polymerization of Colored Compomer Materials
}

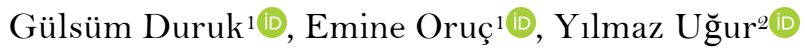

${ }^{1}$ Department of Pediatric Dentistry, Faculty of Dentistry Inonu University, Malatya, Turkey.

${ }^{2}$ Apricot Research Institute, Malatya, Turkey.

Correspondence: Gulsum Duruk DDS, Ph.D., Department of Pediatric Dentistry, Faculty of Dentistry, Inonu University, 44280, Malatya, Turkey. E-mail: durukgulsum@yahoo.com

Academic Editor: Catarina Ribeiro Barros de Alencar

Received: 02 June 2020 / Review: 06 July 2020 / Accepted: 02 September 2020

How to cite: Duruk G, Oruç E, Uğur Y. Evaluation of residual monomer release after polymerization of colored compomer materials. Pesqui Bras Odontopediatria Clín Integr. 2021; 21:e0111. https://doi.org/10.1590/pboci.2021.013

\begin{abstract}
Objective: To evaluate the amount of residual monomers released after polymerization by the compomers in different colors and viscosities over time. Material and Methods: The compomer samples of different colors and viscosities (flowable compomers; blue-pink and packable compomers; $A_{2}$-blue-pink-gold) were prepared in molds with an inner diameter of $5 \mathrm{~mm}$ and a height of $2 \mathrm{~mm}$. In polymerization of samples, a LED unit was used. The amount of monomers released from the samples kept in $75 \%$ ethanol/water solution was measured by a high-performance liquid chromatography (HPLC) instrument in the 10th minute, in the 1st hour, and in the 1st, 7th, and 14th days. For statistical analyses, the paired sample t-test, independent sample t-test, and one-way ANOVA with Tukey's post hoc test were used. Results: The amount of residual monomers released from all materials increased over time. At the end of the 14th day, the most released monomer from all compomer samples was BisGMA. The total amounts of released monomers from the packable compomers were Gold $>$ A2 $>$ blue $>$ pink. The amount of residual monomers released from flowable compomers was higher in blue than in pink. Conclusion: The color and the viscosity are the factors affecting the residual monomer release in compomers.
\end{abstract}

Keywords: Dental Materials; Pediatric Dentistry; Compomers; Chromatography. 


\section{Introduction}

Nowadays, as a result of the developments in adhesive systems and aesthetic expectations, the frequency of the use of resin-containing restorative materials has been increasing steadily. The compomers (polyacid-modified composite resin), the use of which has been increasing in pediatric dentistry as an alternative to amalgam, consist of reaction initiators, organic matrix (Bisphenol-A-glycidyl methacrylate (BisGMA), Urethane dimethacrylate (UDMA), Hydroxyethyl methacrylate (HEMA), and Triethyleneglycol dimethacrylate (TEGDMA)) [1], new monomers such as butan-1,2,3,4-tetracarboxylic acid di-2hydroxyethylmethacrylate ester (TCB) and cycloaliphatic dicarboxylic acid dimethacrylate as functional monomers [2], and reactive inorganic particulate (flouroalumino silicate glass, itterbium trifluoride and barium aluminum silicate fluoro).

In the polymerization reactions of compomers, it is expected that all carbon double bonds of monomers will react and join the polymer chain. However, there are unreacted monomers as a result of resin polymerization, which does not take place at 100\% efficiently depending on many factors such as the polymerization time, the resin material composition, the amount of solvent used and the solvent concentration, ambient temperature and humidity, the presence of oxygen amount in the air, the type of a light-curing unit, the thickness of resin layer [3]. As a result of the incomplete polymerization, these unreacted monomers are called residual monomer. Studies have shown that monomer matrix components have genotoxic, estrogenic, mutagenic, and allergic effects [4].

TEGDMA and UDMA genotoxicity is related to the generation of DNA lesions associated with homologous recombination and gene and chromosomal mutation [5]. The estrogenicity of BisGMA is due to bisphenol A, a major component of BisGMA.

The principal biological activities of estrogens in women include development, growth and maintenance of secondary sex characteristics. In men, however, the physiological significance of estrogens is largely unknown, but they may be involved in the regulation of androgen and estrogen levels as well as sexual behavior [6]. Over-release of the estrogen hormone causes some medical problems such as precocious puberty in girls, enlarged breasts in boys (gynecomastia). In addition, the physiology of the oral cavity are modulated by estrogen. For example, it has been reported that gingival problems related to this hormone increase during pregnancy. Although the estrogenicity of BisGMA-based dental resins is not well-defined, in vitro experiments have identified the components that are released from such resins [7]. However, current findings suggest that the short-term risk of estrogenic effects from dental treatments using BisGMA-based resins is insignificant [6].

The side effects of monomer matrix components such as genotoxic, estrogenic, mutagenic, allergic depend on the type and amount of the released component [8,9]. Therefore, it is essential to define the amount of substances released into the oral environment [10]. However, we have not come across any published studies in the literature on residual monomer release from colored compomers used as a primary tooth filling material in pediatric dentistry.

The polymerization depth of the light-curing unit used in the polymerization of compomer materials affects residual monomers' amount and the degree of conversion [11,12]. It has been reported that the polymerization process, which cannot be performed in sufficient time and efficiency, adversely affects the biological and mechanical properties of the material [13].

In order to make dental treatments more acceptable for children, coloring particles were added, and compomers in different colors were obtained. In this case, factors such as the color of the applied-compomer 
material and the distance between the light-curing unit and the filler became important to obtain sufficient polymerization depth regardless of the irradiation time and reduce the amount of residual monomers [14].

Chromatographic methods are frequently used to measure the amounts of residual monomers [15]. The most commonly used chromatographic methods are high-performance liquid chromatography (HPLC) and Gas Chromatography/Mass Spectrometry (GC/MS). HPLC is the most preferred measurement method because it is easier to control soluble monomers in the mobile phase during the separation process, and the results are reliable, fast, economical, selective and repeatable [16].

In the literature, to our knowledge, there is no study regarding the residual monomer release of the compomers in different colors, which is frequently preferred in pediatric dentistry. Therefore, this study aimed to investigate the amount of residual monomers released from the compomers in different colors and viscosities using the HPLC method after polymerization.

\section{Material and Methods}

The minimum sample size required to detect the significant difference in the mean of the residual monomers should be at least 6 in each group, considering type I error (alfa) of 0.05, power (1-beta) of 0.8, and effect size of 0.9. In our study, each group contained 7 samples.

The compomer materials in 4 different colors with two different viscosities were tested. The monomer contents of the compomers are presented in Table 1.

Table 1. The monomer contents of the compomer materials.

\begin{tabular}{ccccccc}
\hline \multicolumn{2}{c}{ Manufacturer } & \multicolumn{5}{c}{ Materials (VOCO GmbH, Cuxhaven, Germany) } \\
\hline VOCO GmbH & Contains & $\begin{array}{c}\text { Glasiosite Caps } \\
\text { Shade A2 }\end{array}$ & $\begin{array}{c}\text { Twinky Star Compomer } \\
\text { Caps (Blue, Gold, Pink) }\end{array}$ & $\begin{array}{c}\text { Twinky Star Compomer } \\
\text { Flow (Blue, Pink ) }\end{array}$ & $\begin{array}{c}\text { MW } \\
(\mathrm{g} / \mathrm{mol})\end{array}$ & $\eta(\mathrm{Pa})$ \\
& BisGMA & $10-25 \%$ & $10-25 \%$ & $10-25 \%$ & 512 & 1200 \\
& TEGDMA & $2.5-5 \%$ & $\leq 2.5 \%$ & $5-10 \%$ & 286 & 0.01 \\
& UDMA & $5-10 \%$ & $10-25 \%$ & $10-25 \%$ & 470 & 23 \\
& Catalyst & - & - & $\leq 2.5 \%$ & & \\
\hline
\end{tabular}

The study was conducted for six different groups: Group 1: A2 Packable Compomer (Glasiosite); Group 2: Blue Packable Compomer (Twinkystar); Group 3: Pink Packable Compomer (Twinkystar); Group 4: Gold Packable Compomer (Twinkystar); Group 5: Blue Flowable Compomer (Twinkystar); and Group 6: Pink Flowable Compomer (Twinkystar).

The examiners were trained and calibrated prior to the study. For preventing inter-examiner variations, all study samples were prepared by an experienced clinician and HPLC analysis was performed by another experienced examiner. The examiner was trained and calibrated to prepare the compomer samples, standardize the distance between the compomer material and LED unit device, and remove the inhibition layer by polishing. The other examiner was trained and calibrated to prepare ethanol solutions and determine the residual monomers extracted with HPLC device.

In order to prepare the samples for testing, compomer materials were placed into Teflon molds with a height of $2 \mathrm{~mm}$ and a diameter of $5 \mathrm{~mm}$. The samples placed into the molds were compressed between the transparent tape (Miller matrix strip, Dentsply, Brazil) and the two glass plates in order to obtain a flat surface. After removing the glass in the top layer for polymerization, the samples were light-cured with LED units (Woodpecker Med. Instrument, Guilin, China) for polymerization with a wavelength of $480 \mathrm{~nm}$ and a 
light intensity of $1000 \mathrm{~mW} / \mathrm{cm}^{2}$ perpendicular to the surface of the material. The polishing process was performed with Sof-Lex polishing discs (3M ESPE, St Paul, MN, USA) with coarse grains to remove the oxygen inhibition layer after polymerization. Thus, a total of 42 samples with 7 in each group were prepared for the measurement of the amounts of residual monomers.

The $75 \%$ ethanol-25\% pure water solution was prepared. $20 \mathrm{~mL}$ of this solution was placed into each glass vial. The compomer samples were placed into $20 \mathrm{~mL}$ glass vials and kept at $37^{\circ} \mathrm{C}$ during the sampling process, and the extraction was started. $1 \mathrm{~mL}$ samples were taken in 5 different time periods, including the first $10 \mathrm{~min}$ and the $1 \mathrm{st} \mathrm{hr}$, on the $1 \mathrm{st}, 7 \mathrm{th}$, and 14th days, and transferred into $2 \mathrm{~mL}$ amber glass vials. A total of 210 sample solutions were obtained. The solutions were stored at $+4{ }^{\circ} \mathrm{C}$ until the HPLC analysis was done.

The HPLC instrument (UFLC-XR, Shimadzu, Japan) was calibrated. Different concentrations of pure monomer solutions prepared by being diluted from stock solutions were introduced to the instrument. In this process, $80 \%$ acetonitrile / $20 \%$ water mixture was used as a mobile phase. Retention times and linear calibration graphs were determined for each monomer.

The solutions were injected into the HPLC instrument and the detector was set to $254 \mathrm{~nm}$. As the longest retention time was $5 \mathrm{~min}$, each process was carried out with an average of $6.9 \mathrm{MPa}$ pressure for $7 \mathrm{~min}$ to obtain the chromatograms. In these chromatograms, correlation coefficients and calibration equations were obtained with the help of the peaks previously determined for each monomer, and the amount of released monomers (ppm) was determined.

\section{Statistical Analysis}

The data were statistically analyzed using IBM SPSS version 22. The Shapiro-Wilk test, paired sample t-test, independent sample t-test, and one-way ANOVA, with Tukey's post hoc test, were used at a significant level of 0.05 .

\section{Results}

The mean and standard deviation values of the residual monomers released in ppm are presented in Table 2. The residual monomer release continued until the 14th day. In all groups, the most released monomer was BisGMA.

BisGMA monomer release showed the maximum increase between the 1 st and 7 th days in all materials. The material releasing the maximum BisGMA was the gold-colored packable compomer in all time periods $(\mathrm{p}<0.01)$. BisGMA release from blue-colored flowable compomer was more than it was from pink compomer in all time periods, although the difference between them was not statistically significant $(\mathrm{p}>0.05)$. At the end of the 14th day, A2-colored packable compomer released more BisGMA monomer than the pink and blue-colored packable compomers $(\mathrm{p}<0.01)$.

TEGDMA release showed a statistically significant increase in all materials, depending on the time period $(\mathrm{p}<0.01)$. The material releasing the most TEGDMA among the packable compomers was gold-colored compomer $(23.60 \pm 7.95 \mathrm{ppm})$ at the end of the 14th day and it was statistically much higher than A2, blue and pink-colored packable compomers $(\mathrm{p}<0.01)$. The blue-colored flowable compomer released more TEGDMA, although it was not statistically significant, compared to the pink-colored flowable compomer $(p>0.05)$. At the end of the 14th day, there was a statistically significant difference in both blue and pink-colored compomers in terms of TEGDMA release between packable and flowable compomers ( $<<0.01, \mathrm{p}<0.05$ respectively). 
Table 2. The mean and standard deviation values of the amount of the residual monomer released (ppm).

\begin{tabular}{|c|c|c|c|c|c|c|c|c|c|c|c|c|c|c|}
\hline \multirow[t]{2}{*}{ Material } & \multirow[t]{2}{*}{ Groups } & \multicolumn{3}{|c|}{$\begin{array}{l}\text { Between Time Periods } \\
\text { (10th Min-1st Hr) }\end{array}$} & \multicolumn{3}{|c|}{$\begin{array}{c}\text { Between Time Periods } \\
\text { (1st Hr-1st Day) }\end{array}$} & \multicolumn{3}{|c|}{$\begin{array}{l}\text { Between Time Periods } \\
\text { (1st Day-7th Day) }\end{array}$} & \multicolumn{4}{|c|}{$\begin{array}{c}\text { Between Time Periods } \\
\text { (7th Day-14th Day) }\end{array}$} \\
\hline & & 10th min & $\mathrm{MD}(\mathrm{SD})$ & p-value**** & $1 \mathrm{st} \mathrm{hr}$ & $\mathrm{MD}(\mathrm{SD})$ & p-value**** & 1st day & $\mathrm{MD}(\mathrm{SD})$ & p-value**** & 7th day & $\mathrm{MD}(\mathrm{SD})$ & p-value**** & 14th day \\
\hline \multirow[t]{5}{*}{ PC - BisGMA } & G1 & $4.21(1.18)^{\mathrm{a}}$ & $3.02(0.99)$ & $<0.001$ & $7.24(1.38)^{\mathrm{a}}$ & $25.68(2.95)$ & $<0.001$ & $32.9(4.03)^{\mathrm{a}}$ & $34.99(2.53)$ & $<0.001$ & $67.91(5.13)^{\mathrm{a}}$ & $19.62(2.87)$ & $<0.001$ & $78.52(5.85)^{\mathrm{a}}$ \\
\hline & G2 & $2.89(0.44)^{\mathrm{a}}$ & $2.32(0.42)$ & $<0.001$ & $5.21(0.37)^{\mathrm{a}}$ & $16.38(0.91)$ & $<0.001$ & $21.59(1.17)^{\mathrm{a}}$ & $20.37(1.48)$ & $<0.001$ & $41.97(2.57)^{\mathrm{a}}$ & $8.20(1.23)$ & $<0.001$ & $50.17(3.70)^{\mathrm{a}}$ \\
\hline & G3 & $4.77(1.41)^{\mathrm{a}}$ & $1.86(0.29)$ & $<0.001$ & $6.63(1.52)^{\mathrm{a}}$ & $18.52(3.09)$ & $<0.001$ & $25.15(4.18)^{\mathrm{a}}$ & $21.63(2.12)$ & $<0.001$ & $46.78(4.28)^{\mathrm{a}}$ & $6.38(1.28)$ & $<0.001$ & $53.16(4.22)^{\mathrm{a}}$ \\
\hline & G4 & $9.63(4.48)^{\mathrm{b}}$ & $7.28(2.35)$ & $<0.001$ & $16.91(6.43)^{\mathrm{b}}$ & $49.32(14.53)$ & $<0.001$ & $66.23(20.16)^{b}$ & $56.58(16.60)$ & $<0.001$ & $22.81(36.36)^{b}$ & $18.47(8.41)$ & 0.001 & $141.29(4.2 .05)^{b}$ \\
\hline & p-value* & $<0.001$ & & & $<0.001$ & & & $<0.001$ & & & $<0.001$ & & & $<0.001$ \\
\hline \multirow[t]{3}{*}{ FC - BisGMA } & G5 & $2.15(1.09)$ & $2.87(0.53)$ & $<0.001$ & $5.02(0.99)$ & $18.07(3.01)$ & $<0.001$ & $23.09(3.06)^{\mathrm{a}}$ & $22.04(2.42)$ & $<0.001$ & $45.13(5.23)^{\mathrm{a}}$ & $7.17(0.80)$ & $<0.001$ & $52.30(5.78)^{\mathrm{a}}$ \\
\hline & G6 & $2.03(0.60)$ & $2.15(0.30)$ & $<0.001$ & $4.18(0.89)$ & $14.72(0.49)$ & $<0.001$ & $18.90(1.15)^{\mathrm{b}}$ & $18.21(1.11)$ & $<0.001$ & $37.11(2.05)^{\mathrm{b}}$ & $6.12(0.48)$ & $<0.001$ & $43.23(2.47)^{\mathrm{b}}$ \\
\hline & p-value*** & 0.813 & & & 0.124 & & & 0.005 & & & 0.003 & & & 0.002 \\
\hline \multirow[t]{5}{*}{ PC - TEGDMA } & G1 & $1.17(0.15)^{\mathrm{a}}$ & $0.48(0.18)$ & $<0.001$ & $1.65(0.21)^{\mathrm{a}}$ & $5.19(0.52)$ & $<0.001$ & $6.84 \cdot(0.66)^{a}$ & $5.53(0.89)$ & $<0.001$ & $12.37(1.33)^{\mathrm{a}}$ & $2.23(0.79)$ & $<0.001$ & $14.60(1.02)^{\mathrm{a}}$ \\
\hline & $\mathrm{G} 2$ & $0.80(0.08)^{a}$ & $0.37(0.12)$ & $<0.001$ & $1.17(0.11)^{\mathrm{a}}$ & $3.30(0.16)$ & $<0.001$ & $4.50(0.20)^{\mathrm{a}}$ & $3.86(0.40)$ & $<0.001$ & $8.32(0.41)^{\mathrm{a}}$ & $1.98(0.54)$ & $<0.001$ & $10.30(0.70)^{\mathrm{a}}$ \\
\hline & G3 & $1.09(0.14)^{\mathrm{a}}$ & $0.31(0.10)$ & $<0.001$ & $1.40(0.13)^{\mathrm{a}}$ & $3.82(0.56)$ & $<0.001$ & $5.21(0.65)^{\mathrm{a}}$ & $4.51(0.32)$ & $<0.001$ & $9.73(0.77)^{a}$ & $2.34(0.76)$ & $<0.001$ & $12.07(1.37)^{\mathrm{a}}$ \\
\hline & G4 & $2.21(0.90)^{\mathrm{b}}$ & $1.44(0.41)$ & $<0.001$ & $3.65(1.23)^{\mathrm{b}}$ & $8.98(3.42)$ & $<0.001$ & $12.63(4.60)^{b}$ & $7.42(2.15)$ & $<0.001$ & $20.05(6.63)^{\mathrm{b}}$ & $3.55(1.92)$ & 0.003 & $23.60(7.95)^{\mathrm{b}}$ \\
\hline & p-value* & $<0.001$ & & & $<0.001$ & & & $<0.001$ & & & $<0.001$ & & & $<0.001$ \\
\hline \multirow[t]{3}{*}{ FC - TEGDMA } & G5 & $2.11(0.41)$ & $2.42(0.43)$ & $<0.001$ & $4.54(0.45)^{\mathrm{a}}$ & $12.79(1.37)$ & $<0.001$ & $17.33(1.60)^{\mathrm{a}}$ & $8.88(0.86)$ & $<0.001$ & $26.21(2.20)^{\mathrm{a}}$ & $2.27(0.58)$ & $<0.001$ & $28.47(2.14)^{\mathrm{a}}$ \\
\hline & G6 & $2.02(0.22)$ & $1.77(0.22)$ & $<0.001$ & $3.78(0.27)^{b}$ & $9.88(0.52)$ & $<0.001$ & $13.66(0.70)^{b}$ & $6.99(0.68)$ & $<0.001$ & $20.65(0.60)^{b}$ & $2.39(1.27)$ & 0.003 & $23.03(1.36)^{\mathrm{b}}$ \\
\hline & p-value*** & 0.617 & & & 0.003 & & & $<0.001$ & & & $<0.001$ & & & $<0.001$ \\
\hline \multirow[t]{5}{*}{ PC - UDMA } & G1 & $2.65(0.84)^{\mathrm{a}}$ & $1.51(0.67)$ & 0.001 & $4.16(0.80)^{\mathrm{a}}$ & $16.04(1.49)$ & $<0.001$ & $20.20(2.11)^{\mathrm{a}}$ & $21.07(2.32)$ & $<0.001$ & $41.27(3.68)$ & $6.64(2.32)$ & $<0.001$ & $47.91(3.49)^{\mathrm{a}}$ \\
\hline & $\mathrm{G} 2$ & $2.43(0.34)^{\mathrm{a}}$ & $2.05(0.30)$ & $<0.001$ & $4.48(0.27)^{\mathrm{a}}$ & $14.33(0.81)$ & $<0.001$ & $19.80(0.91)^{\mathrm{a}}$ & $17.05(1.29)$ & $<0.001$ & $36.85(2.03)$ & $7.24(1.44)$ & $<0.001$ & $44.09(3.34)^{\mathrm{a}}$ \\
\hline & G3 & $3.95(1.02)^{\mathrm{a}}$ & $1.82(0.57)$ & $<0.001$ & $5.77(1.28)^{\mathrm{a}}$ & $17.18(2.90)$ & $<0.001$ & $22.95(3.71)^{\mathrm{a}}$ & $18.63(2.37)$ & $<0.001$ & $41.59(3.70)$ & $7.40(1.70)$ & $<0.001$ & $48.98(4.31)^{\mathrm{a}}$ \\
\hline & G4 & $8.41(4.02)^{b}$ & $6.27(1.87)$ & $<0.001$ & $14.68(5.52)^{\mathrm{b}}$ & $41.40(12.85)$ & $<0.001$ & $56.08(17.61)^{b}$ & $11.90(49.81)$ & 0.551 & $67.98(44.26)$ & $49.13(58.03)$ & 0.066 & $117.12(37.14)^{b}$ \\
\hline & p-value* & $<0.001$ & & & $<0.001$ & & & $<0.001$ & & & 0.059 & & & $<0.001$ \\
\hline \multirow[t]{3}{*}{ FC - UDMA } & G5 & $1.91(0.76)$ & $3.06(0.54)$ & $<0.001$ & $4.96(0.81)^{\mathrm{a}}$ & $17.85(2.64)$ & $<0.001$ & $22.81(2.89)^{\mathrm{a}}$ & $21.74(2.16)$ & $<0.001$ & $44.55(4.82)^{\mathrm{a}}$ & $7.75(1.61)$ & $<0.001$ & $51.61(5.47)^{\mathrm{a}}$ \\
\hline & G6 & $1.93(0.36)$ & $2.14(0.32)$ & $<0.001$ & $4.08(0.63)^{b}$ & $14.43(0.56)$ & $<0.001$ & $18.51(0.98)^{b}$ & $17.72(1.09)$ & $<0.001$ & $36.23(1.94)^{\mathrm{b}}$ & $7.00(0.81)$ & $<0.001$ & $42.12(2.02)^{\mathrm{b}}$ \\
\hline & p-value*** & 0.942 & & & 0.042 & & & 0.003 & & & 0.001 & & & 0.001 \\
\hline
\end{tabular}

PC: Packable Compomers; FC: Flowable Compomers; MD: Mean Differences; *One-way ANOVA; **Independent Sample t-Test; ***Paired Sample t-Test; SD: Standard Deviation. The different markings show the statistical differences in the same column. 
When UDMA release was evaluated, it was found that the gold-colored packable compomer was the material that showed the maximum UDMA release in all time periods. The maximum UDMA release of all materials except for gold-colored compomer was between the 1st and 7 th days, while the release reached a peak after the 7 th day in the gold-colored compomer. The difference between the amount of UDMA released from the gold-colored compomer and the amount of maximum UDMA released from the other compomers on the 1st day was found to be statistically significant $(\mathrm{p}<0.01)$. While the amount of UDMA released from the blue-colored flowable compomer was greater than that of the pink-colored flowable compomer, this difference was statistically significant only on the 7 th day $(\mathrm{p}<0.05)$.

The release of all monomers increased over time (UDMA: p<0.01; BisGMA and TEGDMA: $p<0.05$ ). The release of the residual monomers over time is presented in Figure 1.

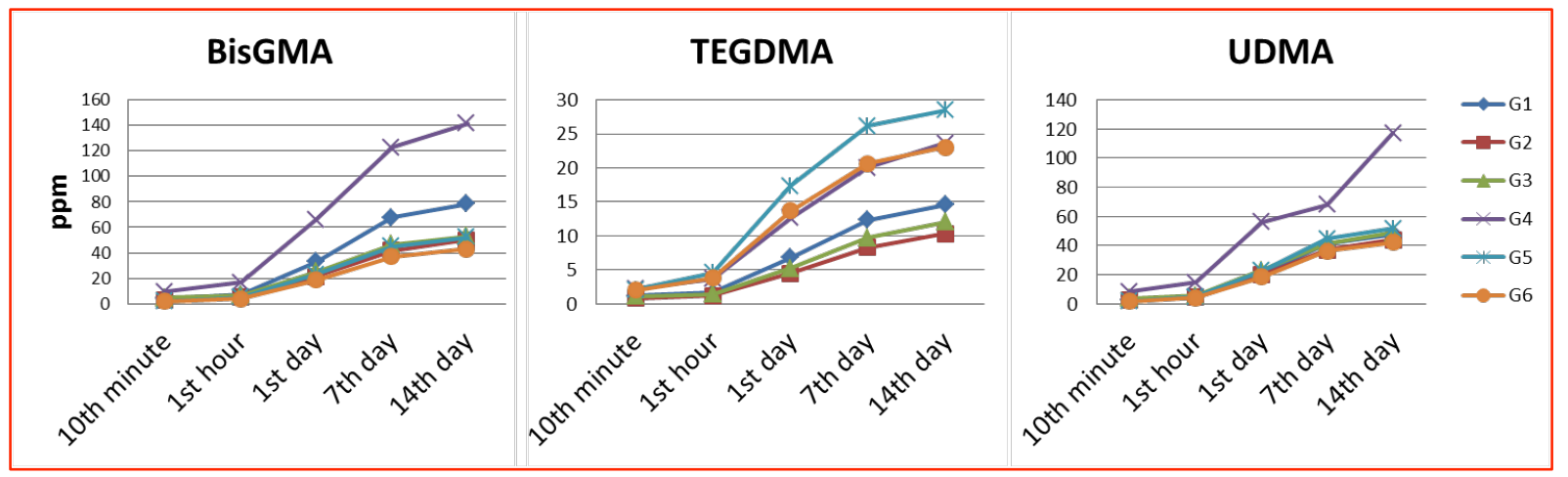

Figure 1. The residual monomer released over time.

\section{Discussion}

In this in vitro study, it was investigated that the amounts of BisGMA, TEGDMA, and UDMA monomers released from compomer materials in different colors and viscosities (packable compomers in 4different colors and flowable compomers in 2-different colors) to $75 \%$ ethanol solution, using the HPLC method, after 10 minute, 1 hour, 1 day, 7 days, and 14 days from the polymerization.

The thickness of resin layer is one of the most important factors affecting polymerization efficiency. The manufacturer's recommendations on product use should also be considered. It is known that resin materials need to be irradiated in $2 \mathrm{~mm}$ layers to increase the polymerization efficiency [17]. In this study, 2 mm high Teflon molds were used.

For the polymerization of resin-based materials, halogen and LED units are frequently used. The researchers reported that the efficiency of polymerization depends on the light-curing unit [12]. Although Spagnuolo et al. [18] reported in their study that halogen light-curing units are more advantageous in terms of cytotoxicity than LED light-curing units, there are also researchers who indicate that almost all of the energy of LED light-curing units is used for polymerization [19]. For this reason, a LED light-curing unit was preferred for polymerization in this study.

After polymerization, the oxygen inhibition layer formed on the resin material's surface is known to contain residual monomers [20]. Therefore, polishing discs were used to remove the oxygen inhibition layer on the obtained samples.

In the study of Sideridou and Achilias [16], resin samples were polymerized in Teflon molds for 60, 80 , and 100 seconds. The researchers reported that the amount of residual monomers declined as the 
polymerization time increased. In our study, the irradiation was carried out for 40 seconds in accordance with the manufacturer's recommendations for the polymerization of the samples.

The most commonly used methods for determining the amount of residual monomers released by resin-based materials are HPLC and GC. HPLC is the most preferred method in terms of cost and accessibility in determining the amount of monomers [21]. In our study, the HPLC system was used to determine the amount of residual monomers.

Although various solvents have been used to evaluate the leaching of monomers, ethanol $75 \%$ was used in many studies to simulate oral conditions. Ethanol $75 \%$ penetrates the matrix, expands the space between polymer chains, attacks cross-linked network, and degrades irreversible materials with a softening effect. So, soluble substances, such as unreacted monomers, may diffuse. On the contrary, artificial saliva penetrates the polymer network to a significantly lower degree [22]. In this study, ethanol $75 \%$ was used as a solvent.

It was reported that monomer release from resin materials was high in the first minutes and this amount continued to decrease over time [6]. The measurement times for the amount of residual monomers released from temporary resin materials were determined by Kavahara et al. [23] as the 1st, 3rd, 6th, 24th hours and 3rd, 7th and 14th days, by Miletic et al. [24] as the 1st, 6th, 24th, 96th hours, and 7th day, by Sasaki et al. [25] before and immediately after the treatment, by Lee et al. [26] before and after the treatment as 5 th min and 7th days, by Moreira et al. [27] before and after the treatment as 30th min., 24th h, 1st week, 1st month, by Michelsen et al. [28], before and after the treatment as 10th min., 24th h, 7th day. In this study, the measurement times were determined as the 10th $\min , 1 \mathrm{st} \mathrm{hr}, 1 \mathrm{st}, 7 \mathrm{th}$, and 14th days for the amount of residual monomers released from colored compomers.

Although there were studies analyzing surface hardness in terms of the effect of color on polymerization [29], there was no study in the literature where polymerization efficiency was measured by HPLC based on the amount of residual monomers in colored compomers. This study is a first in this respect.

The Voco Glasiosite compomer filling material contains 10-25\% BisGMA, 2.5-5\% TEGDMA, 5-10\% UDMA monomers, and the Voco Twinky Star compomer filling material contains 10-25\% BisGMA, $\leq 2.5 \%$ TEGDMA, 10-25\% UDMA monomers. The Voco Twinky Star flowable compomer filling material contains 10-25\% BisGMA, 5-10\% TEGDMA, 10-25\% UDMA, and $\leq 2.5 \%$ catalyst [30]. In our study, BisGMA was found to be the residual monomer with the highest release, while TEGDMA was the least released monomer. BisGMA was the most released monomer despite its high viscosity that makes it difficult to be released. This result is proportional to the amount of monomer in the material. Moldovan et al. [31] stated that BisGMA was released in the highest amount from all experimental resin composites. The results of their HPLC analysis showed that the quantities of residual monomers (TEGDMA and UDMA) were less than $1 \%$, except for BisGMA.

In this study, while the release of BisGMA and UDMA in all materials increased between the 1 st and 7th days, the increase in the amount of TEGDMA took place after the 1st hr in the gold-colored packable compomers and flowable compomers. TEGDMA is a monomer, which reduces viscosity, and the ratio of this monomer is higher in flowable compomers than in the other monomers. The increase in TEGDMA released from the flowable compomers in the early period compared to BisGMA can be explained by the fact that it is diffused faster because it is higher in ratio, and its molecular weight is lower than other monomers. This finding also supports the fact that the amount of residual TEGDMA released from blue and pink-colored flowable compomers is higher than the amount released from packable compomers in the same color. 
The amount of residual monomer release from the resin material is known to vary depending on the factors such as the amount of abrasion occurring on the surface of the material, the type, the size and the combination of the monomers forming the material structure and the changes in the saliva composition [32].

It is also known that the incomplete polymerization will increase the amount of residual monomers, while polymerization is affected by the color of the resin material, the type of the light-curing unit, the irradiation time and the distance between the light-curing unit and the filler [14].

Vandenbulcke et al. [33] compared and examined the penetration depths using a type of penetration test by polymerizing the different color tones of the composites and the compomers and colored compomers under LED and Halogen light-curing units. The lowest penetration depths were found to be in pink and gold colors, whereas in all groups, the highest value was in the blue-colored compomer. Bakkal et al. [34] stated that the gold-colored compomer exhibited a poorer degree of curing, surface hardness, and mechanical properties than berry and silver-colored compomers. Furthermore, Khodadadi et al. [29], in their study on the surface hardness of the Twinky Star different colored compomers depending on their polymerization degree, determined the result as green $>$ orange $>$ lemon $>$ blue $>$ silver $>$ cherry $>$ gold. It is also known that the incomplete polymerization adversely affects the physical properties of the material, leading to deterioration of the surface structure as well as increasing the amount of residual monomers released. Gold-colored compomer, the surface hardness value of which was found to be the lowest by Khodadadi et al. [29] and Bakkal et al. [34], could be related to the fact that among all the monomers, the packable compomer with the highest release at the end of 14 days was gold-colored compomer in our study.

On the other hand, the total amount of released-monomers was higher in A2-colored compomer than in blue and pink-colored compomers $(\mathrm{p}<0.05)$. It was shown that these compomers in both colors, which are frequently preferred in pediatric dentistry, can be used safely in terms of monomer release. These results can be explained by the fact that the light emitted by the light-curing device is scattered in light-colored restorative materials, while it may be absorbed in dark-colored restorative materials [35].

In the literature, there are studies on monomers' cytotoxic effect in the structure of resin-containing dental materials. Walters et al. [36] stated that, According to the cytocompatibility test, UDMA was more cytotoxic at lower concentrations than BisGMA, but the extracts of BisGMA-containing composites were less cytocompatible than the extracts of UDMA-containing composites, and TEGDMA was highly toxic. Issa et al.[32], in their study on the cytotoxic effects of resin monomers on human gingival fibroblasts, reported that the toxicity of TEGDMA was lower than that of BisGMA, whereas the monomer with the lowest toxicity was HEMA. Moharamzadeh et al. [37] emphasized that TEGDMA-containing composite resins produce toxic effects on oral mucosal cells, indicating the toxicity order as BisGMA > TEGDMA > UDMA. In this study, the BisGMA monomer, which was in the first place in the toxicity order indicated by Moharamzadeh et al., was determined as the most released monomer.

The estrogenic effect of bisphenol $\mathrm{A}$ in the content of BisGMA is known. The effects of estrogen in the prepubertal period have been investigated in the literature [6,7], and the cause of high estrogen release has been shown at the basis of many diseases such as precocious puberty and cancer. Pereira et al. [38] stated that, during prepubertal stage, girls had an increased risk of presenting earlier thelarche due to the high estrogen release (over $5 \mathrm{pg} / \mathrm{mL}$ in blood). However, it is stated that the level of bisphenol A in dental materials is so low that this will not affect the estrogen release. In the only study where the estrogenic assay was performed, an increase immediately after the treatment from 0.1 to $1.43 \mathrm{ppm}$ was observed. Only one type of fissure sealant $\left(\right.$ Delton $^{\circledR}$ ) decreased to the levels below $0.1 \mathrm{ppm}$ after $24 \mathrm{~h}$ [39]. In a study evaluating urinary content, 
bisphenol A levels increased slightly immediately after the treatment but not as significant as in saliva [27]. Söderholm et al. [6] suggested evaluating the pharmacokinetics and pharmacodynamics of the long-term release of the contaminants from BISGMA- based resins (that is, bisphenol A) used in the mouth, although the short-term risk of estrogenic effects from dental treatments using BIS-GMA-based resins is insignificant.

Ratanasathien et al. [40], in their study on mouse fibroblasts, reported that the cytotoxic effect of TEGDMA was $124.5 \mu \mathrm{mol} / \mathrm{L}(37.75 \mathrm{ppm})$ and the cytotoxic effect of UDMA was $17.4 \mu \mathrm{mol} / \mathrm{L}(3.90 \mathrm{ppm})$. In this study, at the end of the 14th day, the highest TEGDMA release value was $28.47 \pm 2.14 \mathrm{ppm}$ in blue flowable compomer, while the highest UDMA value was $117.12 \pm 37.14 \mathrm{ppm}$ in gold-colored packable compomer. According to Ratanasathien et al.'s cytotoxicity study [40], although the result of TEGDMA monomer in our study poses not a biological risk, UDMA monomer poses a cytotoxic risk. However, it should be noted that conditions in vitro cannot fully simulate the oral environment even though they are tried to be standardized and there are other factors such as the washing-effect of saliva. Considering the oral conditions, residual monomer release may vary depending on the factors, such as polymerization processes, the chemical composition of saliva, and the stress occurring in resin-based dental restoration.

The limitations of this study can be listed as; (i) all different colored compomers in the color scale could not be included in the study, (ii) the effects of continuously changing oral conditions on the release of residual monomers cannot be fully understood because the ethanol solution cannot fully simulate the saliva, and (iii) no previous studies in this region were available to compare our results. On the other hand, the strength of the study is based on the fact that it is the first study on the subject.

\section{Conclusion}

Based on the amounts of residual monomer release, blue and pink-colored compomers may be preferred to traditional A2 and gold-colored compomers. Gold-colored compomers should not be preferred as restorative materials when considered their possible biological damage to the pulp in deep cavities. Packable compomers should be preferred over flowable compomers. More studies are needed as the cytotoxic effects of the amount of residual monomers released from colored compomers are not known enough.

\section{Authors' Contributions}

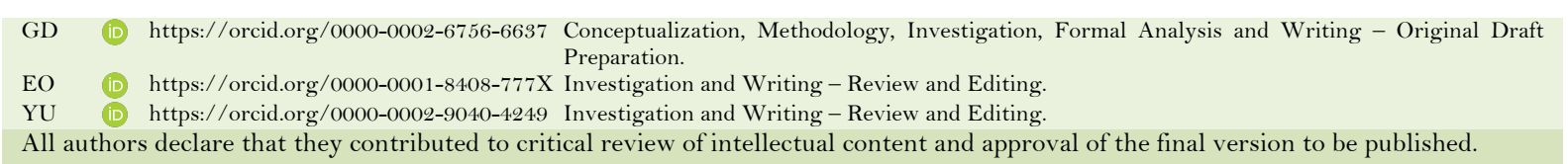

\section{Financial Support}

None.

\section{Conflict of Interest}

The authors declare no conflicts of interest.

\section{Data Availability}

The data used to support the findings of this study can be made available upon request to the corresponding author.

\section{References}


[1] Cramer N, Stansbury J, Bowman C. Recent advances and developments in composite dental restorative materials. J Dent Res 2011; 90(4):402-16. https://doi.org/10.1177/0022034510381263

[2] Schneider B, Baumann M, Watanabe L, Marshall Jr G. Dentin shear bond strength of compomers and composites. Dent Mater 2000; 16(1):15-9. https://doi.org/10.1016/s0109-5641(99)00078-0

[3] Holmes RG, Rueggeberg FA, Callan RS, Caughman F, Chan DC, Pashley DH, Looney SW. Effect of solvent type and content on monomer conversion of a model resin system as a thin film. Dent Mater 2007; 23(12):1506-12. https://doi.org/10.1016/j.dental.2007.01.007

[4] Janke V, Von Neuhoff N, Schlegelberger B, Leyhausen G, Geurtsen W. TEGDMA causes apoptosis in primary human gingival fibroblasts. J Dent Res 2003; 82(10):814-8. https://doi.org/10.1177/154405910308201010

[5] Arossi GA, Lehmann M, Dihl RR, Reguly ML, de Andrade HHR. Induced DNA damage by dental resin monomers in somatic cells. Basic Clin Pharmacol 2010; 106(2):124-9. https://doi.org/10.1111/j.1742-7843.2009.00479.x

[6] Söderholm KJ, Mariotti A. BIS-GMA-based resins in dentistry: are they safe? J Am Dent Assoc 1999; 130(2):201-9. https://doi.org/10.14219/jada.archive.1999.0169

[7] Paula AB, Toste D, Marinho A, Amaro I, Marto CM, Coelho A, et al. Once resin composites and dental sealants release bisphenol-A, how might this affect our clinical management? a systematic review. Int J Environ Res Public Health 2019; 16(9):1627. https://doi.org/10.3390/ijerph 16091627

[8] de Souza Costa C, Hebling J, Hanks C. Effects of light-curing time on the cytotoxicity of a restorative resin composite applied to an immortalized odontoblast-cell line. Oper Dent 2003; 28(4):365-70.

[9] Nalçacı A, Öztan M, Yılmaz Ş. Cytotoxicity of composite resins polymerized with different curing methods. Int Endod J 2004; 37(2):151-6. https://doi.org/10.1111/j.0143-2885.2004.00779.x

[10] Schwengberg S, Bohlen H, Kleinsasser N, Kehe K, Seiss M, Walther U, et al. In vitro embryotoxicity assessment with dental restorative materials. J Dent 2005; 33(1):49-55. https://doi.org/10.1016/j.jdent.2004.08.001

[11] Stahl F, Ashworth SH, Jandt KD, Mills RW. Light-emitting diode (LED) polymerisation of dental composites: flexural properties and polymerisation potential. Biomater 2000; 21(13):1379-85.

https://doi.org/10.1016/s0142-9612(00)00029-6

[12] Kurachi C, Tuboy AM, Magalhães DV, Bagnato VS. Hardness evaluation of a dental composite polymerized with experimental LED-based devices. Dent Mater 2001; 17(4):309-15. https://doi.org/10.1016/s0109-5641(00)00088-9

[13] Elliott J, Lovell L, Bowman C. Primary cyclization in the polymerization of bis-GMA and TEGDMA: a modeling approach to understanding the cure of dental resins. Dent Mater 2001; 17(3):22 1-9.

https://doi.org/10.1016/s0109-5641(00)00075-0

[14] Yap A, Wong N, Siow K. Composite cure and shrinkage associated with high intensity curing light. Oper Dent 2003; 28(4):357-64.

[15] Örtengren U, Wellendorf H, Karlsson S, Ruyter I. Water sorption and solubility of dental composites and identification of monomers released in an aqueous environment. J Oral Rehabil 2001; 28(12):1106-15. https://doi.org/10.1046/j.1365-2842.2001.00802.x

[16] Sideridou ID, Achilias DS. Elution study of unreacted Bis-GMA, TEGDMA, UDMA, and Bis-EMA from light-cured dental resins and resin composites using HPLC. J Biomed Mater Res Part B: Appl Biomater 2005; 74(1):617-26. https://doi.org/10.1002/jbm.b.30252

[17] Caughman WF, Rueggeberg F. Shedding new light on composite polymerization. Oper Dent 2002; 27(6):636-8.

[18] Spagnuolo G, Annunziata M, Rengo S. Cytotoxicity and oxidative stress caused by dental adhesive systems cured with halogen and LED lights. Clin Oral Investig 2004; 8(2):81-5. https://doi.org/10.1007/s00784-003-0247-y

[19] Meyer GR, Ernst C-P, Willershausen B. Decrease in power output of new light-emitting diode (LED) curing devices with increasing distance to filling surface. J Adhes Dent 2002; 4(3):197-204.

[20] Tuna EB, Aktoren O, Oshida Y, Gencay K. Elution of residual monomers from dental composite materials. Eur J Paediatr Dent 2010; 11(3):110-4.

[21] Van Landuyt K, Nawrot T, Geebelen B, De Munck J, Snauwaert J, Yoshihara K, et al. How much do resin-based dental materials release? A meta-analytical approach. Dent Mater 2011; 27(8):723-47. https://doi.org/10.1016/j.dental.2011.05.001

[22] Schulz SD, Laquai T, Kummerer K, Bolek R, Mersch-Sundermann V, Polydorou O. Elution of monomers from provisional composite materials. Int J Polym Sci 2015; 2015:617407. https://doi.org/10.1155/2015/617407

[23] Kawahara T, Nomura Y, Tanaka N, Teshima W, Okazaki M, Shintani H. Leachability of plasticizer and residual monomer from commercial temporary restorative resins. J Dent 2004; 32(4):277-83. https://doi.org/10.1016/j.jdent.2003.12.004

[24] Miletic V, Santini A, Trkulja I. Quantification of monomer elution and carbon-carbon double bonds in dental adhesive systems using HPLC and micro-Raman spectroscopy. J Dent 2009; 37(3):177-84. https://doi.org/10.1016/j.jdent.2008.11.006

[25] Sasaki N, Okuda K, Kato T, Kakishima H, Okuma H, Abe K, et al. Salivary bisphenol-A levels detected by ELISA after restoration with composite resin. J Mater Sci Mater Med 2005; 16(4):297-300.

[26] Lee JH, Yi SK, Kim SY, Kim JS, Son SA, Jeong SH, et al. Salivary bisphenol A levels and their association with composite resin restoration. Chemosphere 2017; 172:46-51. https://doi.org/10.1007/s10856-005-0627-8 
[27] Moreira MR, Matos LG, de Souza ID, Brigante TAV, Queiroz MEC, Romano FL, et al. Bisphenol A release from orthodontic adhesives measured in vitro and in vivo with gas chromatography. Am J Orthod Dentofac 2017; 151(3):477-83. https://doi.org/10.1016/j.ajodo.2016.07.019

[28] Michelsen VB, Kopperud HB, Lygre GB, Bjorkman L, Jensen E, Kleven IS, et al. Detection and quantification of monomers in unstimulated whole saliva after treatment with resin-based composite fillings in vivo. Eur J Oral Sci 2012; 120(1):89-95. https://doi.org/10.1111/j.1600-0722.2011.00897.x

[29] Khodadadi E, Khafri S, Aziznezhad M. Comparison of surface hardness of various shades of twinky star colored compomer light-cured with QTH and LED units. Electron Physician 2016; 8(5):2355. https://doi.org/10.19082/2355

[30] VOCO GmbH. The Dentalists. Safety data sheet (Twinky star), Safety data sheet (Twinky Star Flow). Available from: https://www.voco.dental/en/products/direct-restoration/compomer/twinky-star-twinky-star-flow.aspx. [Accessed on July 10, 2020].

[31] Moldovan M, Balazsi R, Soanca A, Roman A, Sarosi C, Prodan D, et al. Evaluation of the degree of conversion, residual monomers and mechanical properties of some light-cured dental resin composites. Materials 2019; 12(13):2 109. https://doi.org/10.3390/ma12132109

[32] Issa Y, Watts D, Brunton P, Waters C, Duxbury A. Resin composite monomers alter MTT and LDH activity of human gingival fibroblasts in vitro. Dent Mater 2004; 20(1):12-20. https://doi.org/10.1016/s0109-5641(03)00053-8

[33] Vandenbulcke JD, Marks LA, Martens LC, Verbeeck RM. Comparison of curing depth of a colored polyacid-modified composite resin with different light-curing units. Quintessence Int 2010; 41(9):787-94.

[34] Bakkal M, Yilmaz B, Durmus A, Durmus Z, Ozalp S. Polymerization characteristics of colored compomers cured with different LED units. J Appl Biomater Funct Mater 2019; 17(1):2280800019827805. https://doi.org/10.1177/2280800019827805

[35] Hwang SW, Kwon TY, Kim KH, Kwon YH, Kim HI, Lee JB. Optical, mechanical, and chemical properties of colored compomer. Biomed Res 2007; 11:36-42.

[36] Walters NJ, Xia W, Salih V, Ashley PF, Young AM. Poly(propylene glycol) and urethane dimethacrylates improve conversion of dental composites and reveal complexity of cytocompatibility testing. Dent Mater 2016; 32(2):264-77. https://doi.org/10.1016/j.dental.2015.11.017

[37] Moharamzadeh K, Van Noort R, Brook IM, Scutt AM. Cytotoxicity of resin monomers on human gingival fibroblasts and HaCaT keratinocytes. Dent Mater. 2007, 23(1):40-4. https://doi.org/10.1016/j.dental.2005.1 1.039

[38] Pereira A, Corvalan C, Uauy R, Klein KO, Mericq V. Ultrasensitive estrogen levels at 7 years of age predict earlier thelarche: evidence from girls of the growth and obesity Chilean cohort. Eur J Endocrinol 2015; 173(6):835-42. https://doi.org/10.1530/EJE-15-0327

[39] Arenholt-Bindslev D, Breinholt V, Preiss A, Schmalz G. Time-related bisphenol-A content and estrogenic activity in saliva samples collected in relation to placement of fissure sealants. Clin Oral Investig 1999; 3(3):120-5. https://doi.org/10.1007/s007840050089

[40] Ratanasathien S, Wataha J, Hanks C, Dennison J. Cytotoxic interactive effects of dentin bonding components on mouse fibroblasts. J Dent Res 1995; 74(9):1602-6. https://doi.org/10.1177/00220345950740091601 